HUNGARIAN AGRICULTURAL ENGINEERING

$N^{\circ} 26 / 2014$ 54-61

Published online: http://hae-journals.org/

HU ISSN 0864-7410 (Print) / HU ISSN 2415-9751(Online)

DOI: 10.17676/HAE.2014.26.54
PERIODICAL OF THE COMITTEE OF AGRICULTURAL AND BIOSYSTEM ENGINEERING OF THE HUNGARIAN ACADEMY OF SCIENCES and SZENT ISTVÁN UNIVERSITY Faculty of Mechanical Engineering

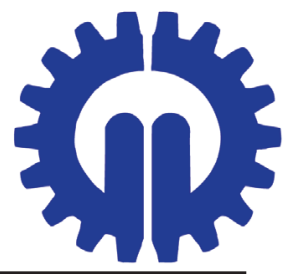

\title{
THEORY OF COOPERATIVE AND NON-COOPERATIVE GAMES IN PRACTICE OF ENVIRONMENTAL OR SUSTAINABLE PROCESS MODELING
}

\author{
Author(s): \\ Cs. Fogarassy
}

Affiliation:

Szent István University, Faculty of Economics and Social Sciences,

Institute of Regional Economics and Rural Development.,1. Páter Károly street, Gödöllö, 2100, Hungary

\section{Email address:}

fogarassy.csaba@gtk.szie.hu

\begin{abstract}
Game theory solutions may find the sufficient balance point to develop decisions in many cases, however, we usually face situations in which, due to the great number and difficulty of factors influencing the circumstances, game theory solutions show more balance points. This makes the selection of the right decision more difficult, or in a worse case, they cannot find solutions (which are difficult to write down with the use of mathematical relations) among the circumstances. Therefore, during processing the relevant literature, I emphasized the introduction of the classic and the new approach of the relations of economic value and sustainability, because the interpretation of sustainability still carries many difficulties which cause the practical implementation to be hardly achieved. Many think that the key of interpreting sustainability is to be able to conceptualize the criteria-system and requirements of sustainability through function-like relations, as well. The mathematical interpretation of sustainability factors, the introduction of sustainable economic balance or company strategies through a game theory approach, and interpreting the search for classic and sustainable economic balance points are challenges for which many theories, scientific papers, generative formulas and a great number of scientific attempts have been connected for decades now, but none of them has been fully successful.
\end{abstract}

\section{Keywords}

game theory, cooperative games, non-cooperative games, sustainable economic, Nash equilibrium, zero sum games, oligopolistic games, multi-purpose programming

\section{Introduction}

Economics basically states that rational behavior is based on consistent preferences. If a person's preferences satisfy some basic needs or consistence-criteria, then these preferences can correspond to a well-defined usefulness function. Therefore, rational behavior can be viewed as the maximization of the usefulness function. This leads to the fact that we can call this definition of rational behavior the usefulness theory, says Harsányi (1995a).

However, Harsányi also states that there is much evidence that this hypothesis is not valid, and that economics is rather based on the hypothesis that the preferences of people are completely consistent (1995). Most economists view this as a useful and simplifying hypothesis, arguing that economics, which is built upon this hypothesis, can offer mostly good, even if not perfect forecasts of the machinations of the economic system.

Economic policy argues about how the happenings of economy affect the behavior of society. To prove that this is a basic part of everyday life, e.g. the fact that the average family size has been in decline in most countries in the last few decades, is well-based proof. The reason for this is that the economic pros of a larger family were greatly diminished while the cost was heightened due to the effects of urbanization and intensive technological advancement. The preference of a smaller family model and the consumption and living standards of families consisting of 3-4 people therefore took an important role in the process of optimum search (Hobson, 2012).

In order to link not only decision aspects based on economic indexes, but actual factors that have an impact on living standards to the choice preferences of various families, e.g. the criteria system of their purchases, we have to aim at creating a comparison method which can be used for many different attributes that aren't dependent on each other (Vincze, 2009). If in the course of our decisions we have to form a judgment on a system or an object based on more characteristics simultaneously and these characteristics mean a mostly controversial characteristic set, while the sorting principles being connected to this show complicated contexts, then we may turn to mathematical modeling and its software applications for help. Therefore, to start the examination of the multipurpose systems, we should assign the most important criteria. We have to accept that fact at the time of the optimization of more opportunities, that according to Axelrod (1984) we can't optimize all characteristics taken into consideration simultaneously. The simple reason for this is that the optimum of the attributerepresenting objective functions usually won't correspond to the same alternative all the time.

\section{Method}

We can generally say about the designation of the criteria system that we cannot take each single characteristic that influences our system or the function of its examined object into consideration. That is why we have to select those that are worth the additional investigation from the essential characteristics. The various 
characteristics have to be totally independent of each other. This is very important during the course of the selection in order to have no overlaps between the single criteria, since these cross characteristics may cause unnecessary examinations and a loss of time during the analysis. Therefore, during the multipurpose optimization tasks, we may have the following tasks in order for the process of the model creation, and the criteria system of problem solution to take shape (Forgó et al., 2005):

1. Designation of criteria system (and also, major attribute sets)

2. Independence analysis of attribute sets (avoiding overlaps between attributes)

3. Designation of choice variables and parameters in attribute sets (deterministic, or stochastic - in other words, realized with some level of probability - marking)

4. Designation of binding criteria related to set (creation of sets)

5. Designation of possible criteria of the criteria system, and the number of objective functions in set (the number of objective functions is finite)

6. Search of optimum for objective functions

The general form of the multi-purpose programming task according to Molnár et. al. (2010a) is as follows (if we assume that $\mathrm{D}(\varphi \mathrm{k})=\mathrm{L}$ and in case of any $X \in, \varphi_{\mathrm{k}}(\mathrm{X})$ is a real number):

$$
\varphi_{k}(X) \rightarrow \max \quad(k=1,2, \ldots \ldots, n)
$$

$\mathrm{X}$ - system of choice variables

$\mathrm{L}$ - possible set of values for choice variables

$\mathrm{D}\left(\varphi_{\mathrm{k}}\right)$ - choice domain of function

$\mathrm{n}$ - number of objective functions

$\varphi_{\mathrm{k}}=\mathrm{k}$ - th objective function, in other words, the payoff function

We have to note, however, that the need for multipurpose problem solving is not the requirement of the present, since János Neumann already laid down the function-like necessities of the behaviors attached to rational decisions in 1928, and, in his work written together with Oskar Morgenstern entitled „Game Theory and economic behavior," wrote it down in detail already in 1944 (Neumann - Morgenstern, 2007)

\section{Results}

Search for points of equilibrium in non-cooperative games

Game Theory fundamentally deals with the solution of multipurpose problems, that is, with so-called strategic games. Game Theory is one of the branches of mathematics with an interdisciplinary character and it primarily tries to tackle the question of what is rational behavior in situations where the possible choices of the participants influence the result of the decisions of all participants. A problem or problem solution can be called a strategic game if the decision makers may have influence on the outcome of the game between the existing conditions and the framework of rules (Mezö, 2011a).

We always assume that we may characterize the outcome of the game for all players with an objective function in Game Theory solutions, in other words, the payoff function already mentioned. And for the various players (characters), the bigger the payoff function value, the more beneficial the outcome of the game is. The players' decisions, in other words, the outcome of the decisions onto the final result, are what we call the player's strategy. We know two- or multi-person variants of Game Theory solutions. The Game Theory solution is non-cooperative if the players or characters compete with each other during problem solving, while the game is obviously cooperative if cooperation takes shape between the players. The importance of searching for points of equilibrium is emphasized in Game Theory. If the search aims at the fact that, when including all players' strategies, the benefit of one player won't change in case of him changing his strategy and none of the other players do so either, we call it the Nash equilibrium (Szidarovszky - Molnár, 1986).

The theory of the Nash equilibrium originates from John Nash, who was rewarded with a Nobel-prize for the development of the theory at the same time as János Harsányi, exactly 20 years ago. It was shown through Nash's equilibrium theory that all finite games have at least one point of equilibrium. Nash divided the optimization games into cooperative and non-cooperative types. According to his thesis, the cooperative game is the kind where cooperation between players is simply enforced. According to him, we can only talk of non-cooperative games if agreement between the players is impossible to enforce. A non-cooperative game in the case of various strategies of players can only be called stable if the so-called Nash equilibrium is present. In the case of Nash equilibrium, the strategies of the various players are the optimal replies to the others' strategies, so there aren't any players who want to break this status quo by choosing new, different cooperative strategies. The game will not be stable if it is not in the Nash equilibrium point, because there is always at least one player in this case to whom his strategy does not mean the best answer in the given situation, and therefore he will be interested in looking for a new strategy for himself (Harsányi, 1995b).

As I've already mentioned, the equilibrium situation may also be stable in case of cooperative games if one of the strategic combinations isn't in accordance with the rest of the strategies, because the strategic cooperation will sooner or later be enforced. However, in economic life we mostly face strategy creations that do not take each other into consideration and run beside each other or that do not take the multipurpose decision process or the designation of choice optimum into consideration (Molnár Kelecsényi, 2009). From the European or economic policy practice, we have a good example for this: the bulk of strategies concerning environment protection or renewable energetic developments, since we often face a strategy creation with a contradictory direction here.

A principle is that developments with an environment protection aim have an opposite direction to that of the priority system of economic development (f. e. the program taking aim at the reduction of greenhouse gas and fossil energy use takes aim at the minimization of the intake, while the other one at the increase of a polluter energy source). A good example for this is two of the EU's main strategies: EU Low-carbon Roadmap 2050 vs. Nuclear Power in France (2014). 58 nuclear power plants operate currently in France, and additional developments are going on, while Germany just decided that by 2020, all (now 8 operating plants) of them will be shut down.

In case of cooperative games, the selected strategy may also be stable even if a strategy combination is not in Nash equilibrium but the players come to an agreement that this strategy combination will be selected. During the course of the presentation of this search dilemma for the Nash equilibrium point - in case of non-cooperative games - I lean fundamentally on István Mező's study (2011b), „Game Theory,” while if I differ from this, I'll note it separately in the description.

\section{Definition 1:}

According to the Definition of the Nash equilibrium:

The point of equilibrium or strategy for an $\mathrm{n}$ player $J=\left(n, S,\left(\varphi_{i}\right)_{i=1}^{n}\right)$ game is a point (strategic $\left.n\right)$, for which

$$
\varphi_{i}\left(x_{1}^{*}, \ldots, x_{i-1,}^{*} x_{i}^{*}, x_{i+1,}^{*}\right) \geq \varphi_{i}\left(x_{1}^{*}, \ldots, x_{i-1}^{*}, x_{i}, x_{i+1}^{*}\right)
$$

holds true for every $i=1, \ldots \ldots, n$ player. The point of equilibrium is therefore called a Nash equilibrium. [Shortened: 


$$
\varphi_{k}\left(x_{1}^{*}, \ldots, x_{k,}^{*}, \ldots x_{n,}^{*}\right) \geq \varphi_{k}\left(x_{1}^{*}, \ldots, x_{k}, \ldots x_{n,}^{*}\right) .
$$

where $k=1,2, \ldots n]$.

If 1.1.'s equality is strict, then it is called a strict equality.

If we do not state anything else, we say it's the point of equilibrium is non-strict.

The i-th player can maximize his own payoff if he plays the equilibrium strategy, namely, $x_{i}^{*}$ if all the other players do the same. We will need the following definitions to find the state of equilibrium:

\section{Definition 2:}

An $n$ - player $J$ game is called a constant sum if the rewards and demerits earned by the player is a constant $\mathrm{c}$ value, regardless of strategy.

With formula:

$$
\sum_{i=0}^{n} \varphi_{\mathrm{i}}(\mathrm{x})=c(x \in S) .
$$

If $c=0$, the game is called zero sum game.

Two-player, zero sum games are useful for demonstrating the definition of the point of equilibrium better. If we take a point of $\left(x_{1}^{*}, x_{2}^{*}\right) \in S$ equilibrium, based on (1.1)

$$
\varphi_{1}\left(x_{1}^{*}, x_{2}^{*}\right) \geq \varphi_{1}\left(x_{1}, x_{2}^{*}\right) \text { for every } x_{1} \in S_{1}
$$

and

$$
\varphi_{2}\left(x_{1}^{*}, x_{2}^{*}\right) \geq \varphi_{2}\left(x_{1}^{*}, x_{2}\right) \text { for every } x_{2} \in S_{2} .
$$

The game is zero sum, therefore:

$\varphi_{1}\left(x_{1}, x_{2}\right)+\varphi_{2}\left(x_{1}, x_{2}\right)=0, \varphi_{2}\left(x_{1}, x_{2}\right)=-\varphi_{2}\left(x_{1}, x_{2}\right)$, and:

$$
-\varphi_{1}\left(x_{1}^{*}, x_{2}^{*}\right) \geq-\varphi_{1}\left(x_{1}^{*}, x_{2}\right) .
$$

If we rearrange the formula:

$$
\varphi_{1}\left(x_{1}^{*}, x_{2}^{*}\right) \geq \varphi_{1}\left(x_{1}^{*}, x_{2}\right) .
$$

and including (1.2) inequality as well, we get:

$$
\varphi_{1}\left(x_{1}, x_{2}^{*}\right) \leq \varphi_{1}\left(x_{1}^{*}, x_{2}^{*}\right) \leq \varphi_{1}\left(x_{1}^{*}, x_{2}\right) .
$$

This inequality system states that from a $\left(x_{1}^{*}, x_{2}^{*}\right)$ point of equilibrium, if player one leaves with a strategy different from $x_{i}^{*}$, the payoff function can only be either lower or equal. If player two is the one who leaves, the payoff function of player one will either be greater or equal, and since the game is zero sum, this would mean that his ,payment” won't be greater.

\section{Definition 3:}

Let's look at two games, which only differ in payoff functions:

$$
J=\left(n, S,\left(\varphi_{i}\right)_{i=1}^{n}\right) \text { and } J^{\prime}=\left(n, S,\left(\varphi_{i}^{\prime}\right)_{i=1}^{n}\right) .
$$

$J$ and $J^{\prime}$ are called strategically equivalent, if there's a positive number, and there are $b_{i}$ numbers, where $\left.i=1, \ldots, n\right)$, that

$$
\varphi_{i}^{\prime}(x)=a \varphi_{i}(x)+b_{i} \text { for every } x \in S \text { and } i=(1, \ldots, n) \text {. }
$$

The following thesis describes the obvious fact, which is also clear on the basis of simple intuition and logic that strategically equivalent games must always be played in the exact same manner.

\section{Thesis 1:}

The points of equilibrium for strategically equivalent games are the same.

Proof: Let

$$
J=\left(n, S,\left(\varphi_{i}\right)_{i=1}^{n}\right) \text { and } J^{\prime}=\left(n, S,\left(\varphi_{i}^{\prime}\right)_{i=1}^{n}\right)
$$

be our strategically equivalent games, and let

$$
\left(x_{1}^{*}, \ldots, x_{n}^{*}\right) \in S
$$

be one of the points of equilibrium for game $J$. According to the definition for point of equilibrium (1.1), at $i$-th player's every $x_{i} \in S_{i}$ strategy:

$$
\varphi_{i}\left(x_{1}^{*}, \ldots . ., x_{i-1}^{*}, x_{i}, x_{i+1}^{*}, \ldots . x_{n}^{*}\right) \leq \varphi_{i}\left(x_{1}^{*}, \ldots . ., x_{i-1}^{*}, x_{i}, x_{i+1}^{*}, \ldots . x_{n}^{*}\right)
$$

Since $J^{\prime}$ is strategically equivalent to $J$, then with the constants a $>0$ and $b_{i}$ :

$$
\begin{aligned}
& a \varphi_{i}^{\prime}\left(x_{1}^{*}, \ldots, x_{i-1}^{*}, x_{i}, x_{i+1}^{*} \ldots ., x_{n}^{*}\right)+b_{i} \leq \\
& \leq a \varphi_{i}^{\prime}\left(x_{1}^{*}, \ldots, x_{i-1}^{*}, x_{i}, x_{i+1}^{*} \ldots ., x_{n}^{*}\right)+b_{i} .
\end{aligned}
$$

which, due to being positive results in

$$
\varphi_{i}^{\prime}\left(x_{1}^{*}, \ldots, x_{i-1}^{*}, x_{i}, x_{i+1}^{*} \ldots . ., x_{n}^{*}\right) \leq \varphi_{i}^{\prime}\left(x_{1}^{*}, \ldots, x_{i-1}^{*}, x_{i}, x_{i+1}^{*} \ldots \ldots, x_{n}^{*}\right)
$$

And this means $\left(x_{1}^{*}, \ldots x_{n}^{*}\right)$ is a point of equilibrium for $J^{\prime}$.

\section{Thesis 2:}

For every constant sum game, there is a zero sum game that is strategically equivalent to it, therefore having an overlap in points of equilibrium.

Proof: Let us simply subtract the constant sum from the value of payoff functions. This results in a zero sum in every possible outcome, and the new game remains strategically equivalent to the old one. Because of our previous thesis, their points of equilibrium are also the same. If we look at constant sum games, it's enough for us to only concern ourselves with the zero sum variants only. Furthermore, a two-player game is zero sum if one player wins exactly as much as the other one loses (or the opposite). Therefore:

$$
\varphi_{2}\left(x_{1}, x_{2}\right)=-\varphi_{1}\left(x_{1}, x_{2}\right)
$$

we can use this function, and we don't actually need a payoff function altogether, we simply use $\varphi-$ instead of e.g. $\varphi_{1}$.

\section{Theoretical correspondences of finite games}

If an $n$ - player game's $S_{k}(k=1,2, \ldots . . n)$ strategy sets are finite, then we say the game is of a finite kind. Games of a finite kind can typically be either two-player or $n$-player, meaning more than two players. In the function-like correspondence system of games of finite kind, it can be made obvious that during the solution of multi-purpose problems, the strategic sets, in other words, the defined parameters, or criteria groups are finite, but are always more than two. Since the project development decision process of our analyzed problem, the investments related to environmental defense and renewable energetic developments is $n$ - player $(n \geq 2)$, it's advisable for us to analyze the behavior of multi-person games (Szidarovszky et. al 2013). We do assume however, that the game isn't concluded in a mere moment, but at previously designated $t_{0}, t_{1}, t_{2}, \ldots$. times, where only one player can modify the state of the game due to a previously set consecution. This state can be depicted with a tree graph (refer to Figure 1). This process in search of optimum is quite similar to a $3 \times 3 \times 3$ Rubik's Cube's solution process alternatives, since we 
decide by the cube's randomness, in other words, unsortedness, which shortest combination row (or depth level) we choose to heighten the level of sortedness, or simply, the solution of the cube in the case of layer by layer solution method (G. Nagy, 2008).

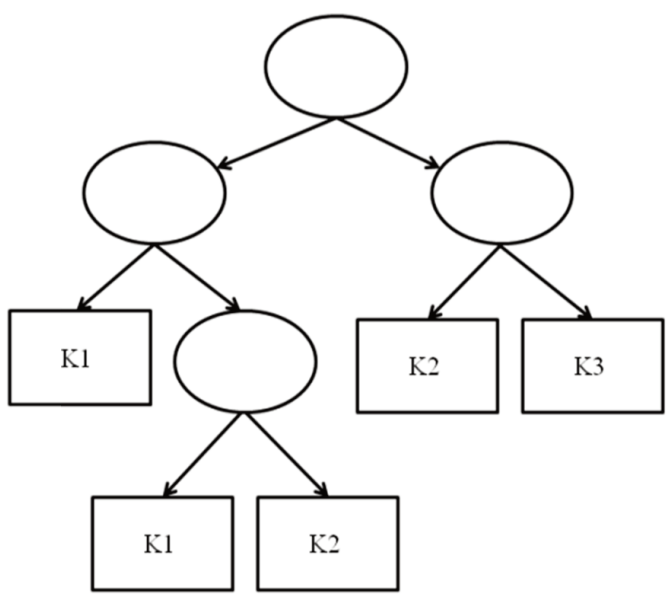

$\mathbf{t}_{0}$

$\mathbf{t}_{1}$

$\mathbf{t}_{2}$

Figure 1. Decision tree graph with pre-determined times $\left(t_{0}, t_{1}, t_{2}, t_{3}\right)$ and combination alternatives $\left(K_{1}, K_{2}, K_{3}\right)$ Source: self-made (based on MIEA, 2005)

The state of the system made by the players, in other words, the multi-purpose problem solving, can be illustrated with a problem tree, or tree graph, however, let's assume (according to Forgó et al. 1999) that:

a) the tree has a starting point (state of $t_{0}$ time, which goes towards $t_{1}, t_{2} \ldots ., n$ ),

b) one player is assigned to the starting point and every branching point in accordance with a previously defined rule; this player can choose between the various, finite number of edges, and relocates the system's state from this edge's starting point to the conclusion point,

c) every player knows the game's current progress in every $t_{k}$ $(k \geq 0)$ time point, including all the states of the game up to it,

d) in all the conclusion points of the tree diagram, all players have a payoff function value known to them.

Furthermore, let's assume that there are no players assigned to some of the peak points of the tree graph and the progression from here happens randomly through predetermined distributions, meaning the players don't have choices, or do, but only symbolically. For the sake of uniformity, let's assign a player to these peak points as well, but their decisions are merely formal. In this case, the payoff functions of the game should be replaced with anticipatory values based on the random distributions. This game can be illustrated with a finite tree graph and is called a perfect information extensive-form game (Molnár - Szidarovszky, 1995; Molnár 1994)

\section{Thesis 3:}

Every perfect information extensive-form game that can be depicted with a tree graph has at least one point of equilibrium.

Proof: Let $I$ mark the starting point of the tree graph, while $V_{l}$, $V_{2}, \ldots . . V_{M}$ marks the conclusion points. In our tree graph's case, there is a single route leading from $I$ to every $V_{k}$ conclusion point. The length of the longest route is called the tree graph's length. We will prove the thesis with the complete induction of the game's tree graph's length, according to Molnár and Szidarovszky (2011a).

If $h(F)=0$, then the tree graph only consists of the starting point This means that players only have a single strategy. Furthermore, in this case, this single strategy is obviously the point of equilibrium. Let's say that $h(F) \geq 1$. Let m mark the number of edges originating from the starting point, and let $U_{1}, U_{2}, \ldots \ldots, U_{m}$ be the conclusion points of the edges originating from the starting point. Furthermore, let $F_{k}(k=1,2, \ldots, m)$ mark the maximum partgraph with the $U_{k}$ starting point, excluding the $I$ peak point. It is obvious that $F_{k}$ 's conclusion points are from $F$ 's points. Let

$$
\Gamma_{k}=\left(n ; S_{1}^{(k)} \ldots, S_{n}^{(k)} ; \varphi_{1}^{(k)} \ldots, \varphi_{n}^{(k)}\right)
$$

mark the original game narrowed to $F_{k}$, meaning that to $F_{k}$ 's peak points, we assign players also assigned to them in $F$, and to its conclusion points, we assign the payoff function values of $F$.

In this case, it's obvious that $h\left(F_{k}\right)<h(F)$, therefore, according to our induction thesis, $\Gamma_{k}$ games have

$$
x^{(k) *}=\left(x_{1}^{(k) *}, \ldots \ldots x_{n}^{(k) *}\right)
$$

existing points of equilibrium. Let us say that in the game of graph $F$, we assigned player $i_{0}$ to the starting point.

a) Let us assume that player $i_{0}$ can freely decide between the $\mathrm{m}$ routes originating from the starting points. In this case, it's obvious that if $\mathrm{i} \neq i_{0}$ then $S_{i_{0}}=X_{k=1}^{m} S_{i}^{(k)}$

$$
S_{i_{0}}=X_{k=1}^{m} S_{i}^{(k)} x\{1,2, \ldots \mathrm{m}\} .
$$

Therefore, player $i_{0}$, apart from advancement in graph $F_{k}$, has to decide the advancement from the starting point as well. Let $\varphi_{\mathrm{i} 0}$ mark $\left(x^{\left.(k)^{*}\right)}\right.$ numbers' highest index, where the strategic $n$ bundle obviously offers the point of equilibrium for the game, in case of $\Gamma_{k}(1 \leq k \leq m)$ games' $x^{(k)^{*}}$ points of equilibrium, supplemented by advancement from starting point $I$ to point $U_{k 0}$.

b) Let us assume that player $i_{0}$ randomly makes a choice at the start of the game from a pre-determined $p_{1}, p_{2}, \ldots \ldots, p_{m}$ probability distribution. In this case, the Cartesian product of $\Gamma_{k}$ games' $x^{(k)^{*}}$ points of equilibrium gives the original game's point of equilibrium. To prove this, let's say that in case of $k=$ $1,2, \ldots, m$ and $i=1,2, \ldots, n$ :

$$
\varphi_{i}^{(k)} x^{(k) *} \geq \varphi_{i}^{(k)}\left(x_{1}^{(k) *}, x_{i}^{(k) *} \ldots . x_{n}^{(k) *}\right) .
$$

with arbitrary $x_{i}^{(k)} \in S_{i}^{(k)}$, multiplying the inequality by $p_{k}$ and in case of $k=1,2, \ldots, m$, we obtain the inequality defining the point of equilibrium for the original game by addition.

The thesis was proven based on Molnár - Szidarovszky (2011b), who stressed during the proof that the multipurpose problem solving is primarily suitable for the solution of smaller tasks, in other words, forming short tree graphs. Here, we get games that can be depicted with zero length tree graphs, in case of which staying in their only point means the only point of equilibrium. However, the number of the short tree graphs may grow so much in case of bigger tasks that it makes searching for points of equilibrium impossible. This can be recognized with experimentation - trial and error.

Games of infinite kind-Game Theory models with one or more points of equilibrium

Games with a single point of equilibrium

The simplification of the points of equilibrium for any given game can be proven by e.g. proving the problem of one of the exact fixed point-problems, which is equivalent to the problem of equilibrium. During the proof, I basically follow Szidarovszky's logical process, while if I differ from this, I'll note it separately in the description.

A single-variable, fixed point problem usually means the solution of the $f(x)=x$ equation. It is a known fact that if $\mathrm{f}$ is a decreasing function of $\mathrm{x}$, there can be no more than one solution. 
Let's try to generalize this monotonization criteria to a multidimension case. Therefore, let $\mathbf{f}$ be a vector-variable, vector-value function, $\mathbf{f}: \mathrm{R}^{\mathrm{n}} \longrightarrow \mathrm{R}^{\mathrm{n}}$. The following example shows that strict monotony by component still won't guarantee exactness (Szidarovszky, 1978a).

Example. Let's look at the

$$
\begin{aligned}
& x=-x-2 y \\
& y=-2 x-y
\end{aligned}
$$

fixed point-problem, given by

$$
f(x, y)=\left(\begin{array}{l}
-x-2 y \\
-2 x-y
\end{array}\right)
$$

imaging. Both components in both their variables are strictly decreasing functions, and yet there are an infinite number of fixed points:

$$
\mathrm{y}-\mathrm{x} \text {. }
$$

We can show however, that a different type of monotony is sufficient to prove the exactness of fixed points.

Definition. Let $\mathrm{D} \subseteq \mathrm{R}^{\mathrm{n}}$ be a convex set. We call an $\mathrm{f}: \mathrm{D} \rightarrow \mathrm{R}^{\mathrm{n}}$ function monotone, if for any $\mathrm{x}, \mathrm{y} \in \mathrm{D}$ :

$$
(x-y) T(f(x)-f(y)) \geq 0 .
$$

function $\mathrm{f}$ is called strictly monotone, if for any $\mathrm{x}, \mathrm{y} \in \mathrm{D}$ and $\mathrm{x} \neq \mathrm{y}$ :

$$
(\mathrm{x}-\mathrm{y})^{\mathrm{T}}(\mathrm{f}(\mathrm{x})-\mathrm{f}(\mathrm{y}))>0 .
$$

We can easily see that if $f$ is monotone, the imaging cannot have two different fixed points. Let us assume in spite of this that $\mathrm{x}$ and $\mathrm{y}$ are both fixed points.

$$
\begin{gathered}
0<(x-y)^{\mathrm{T}}(\mathrm{x}-\mathrm{y})=(\mathrm{x}-\mathrm{y})^{\mathrm{T}}(\mathrm{f}(\mathrm{x})-\mathrm{f}(\mathrm{y})) \\
=-(\mathrm{x}-\mathrm{y})^{\mathrm{T}}((-\mathrm{f}(\mathrm{x}))-(-\mathrm{f}(\mathrm{y}))) \leq 0
\end{gathered}
$$

This is obviously a contradiction.

We can easily check the monotony of the imaging, as shown by the next thesis:

Thesis. Let $\mathrm{D} \subseteq \mathrm{R}^{\mathrm{n}}$ be a convex set and $f: \mathrm{D} \rightarrow \mathrm{Rn}$ function continuously differentiable. Let $J(\mathrm{x})$ mark $f$ 's Jacobi matrix at point $x$.

a) If $\mathrm{J}(\mathrm{x})+\mathrm{J}^{\mathrm{T}}(\mathrm{x})$ is positive semi-definite in all $\mathrm{x} \in \mathrm{D}$ points, $\boldsymbol{f}$ is monotone

b) If $\mathrm{J}(\mathrm{x})+\mathrm{J}^{\mathrm{T}}(\mathrm{x})$ is positive definite in all $\mathrm{x} \in \mathrm{D}$ points, $\boldsymbol{f}$ is strictly monotone.

\section{Proof.}

For a fixed $\mathrm{x}, \mathrm{y} \in D$, let's introduce the

$$
g(t)=f(y+t(x-y))
$$

scalar variable function. Obviously

$g(0)=f(y)$ and $g(1)=f(x)$,

therefore

$$
\mathrm{f}(\mathrm{x})-\mathrm{f}(\mathrm{y})=\int_{0}^{1} J(\mathrm{y}+\mathrm{t}(\mathrm{x}-\mathrm{y}))(\mathrm{x}-\mathrm{y}) d t .
$$

Let's multiply both sides from the left by the $(\mathrm{x}-\mathrm{y})^{\mathrm{T}}$ linear vector, and we get:

$$
\begin{aligned}
& (\mathbf{x}-\mathbf{y})^{\mathrm{T}}(\mathbf{f}(\mathbf{x})-\mathbf{f}(\mathbf{y}))=\int_{0}^{1}(x-y)^{T} \mathrm{~J}(\mathrm{y}+\mathrm{t}(x-\mathrm{y}))(\mathrm{x}-\mathrm{y}) \mathrm{dt} \\
= & \frac{1}{2} \int_{0}^{1}(\boldsymbol{x}-\boldsymbol{y}) T\left\{\mathrm{~J}(\mathrm{y}+t(\mathrm{x}-\mathrm{y}))+\mathrm{J}^{\mathrm{T}}(\mathrm{y}+t(\mathrm{x}-\mathrm{y}))\right\}(\mathrm{x}-\mathrm{y}) d t
\end{aligned}
$$

In the previous step, we used the fact that for any given $u \in \mathrm{D} \cdot \mathrm{R}^{\mathrm{n}}$ vector and $n \times n$ type $J$ matrix:

$$
\mathbf{u}^{\mathrm{T}} \mathrm{J} \mathbf{u}=\mathbf{u}^{\mathrm{T}} \mathbf{J}^{\mathrm{T}} \mathbf{u},
$$

since both sides are scalar, and each other's transposes. If $\mathbf{J}+\mathbf{J}^{\mathrm{T}}$ is positive semi-definite, the right side isn't negative, and if it's positive definite, then it's positive, respectively. Having precise knowledge about imaging is an absolute necessity to use the results above, which isn't always possible, due to the need for knowledge on solving optimum-problems. This is why results which are based on the attributes of strategic sets and payoff functions are very important (Molnár - Szidarovszky, 2011c; Mészáros, 2005).

Two-player games of an infinite kind: biomass-management

Let's take a builder depot as an example, which is in contract with a logging firm for firewood (biomass) supply. For the sake of simplicity, I'll only include one type of firewood, meaning one type of product. According to our hypothesis, the distribution of the purchases arriving to the builder depot is exponential, meaning it's a question of incoming needs per timeframe (Molnár Szidarovszky, 1995):

$$
g(x)=\alpha e^{-\alpha x}(\alpha>0, x>0) .
$$

To understand the example, we will be using the following: $a_{1}$ is the total profit from selling one unit of product, meaning firewood, if it supplies from its own stock. $a_{2}$ will be the total profit of the builder depot, which comes from purchased firewood $\left(a_{2}<a_{1}\right) . b_{1}$ will be the deposit cost of the builder depot per unit. $b_{2}$ will be the logging firm's deposit cost per unit.

The strategies of both the builder depot and the logging firm can be described by one number: the size of their stock. If $y$ marks the builder depot's stock while $z$ marks that of the logging firm, then the builder depot's anticipatory profit is as follows:

$$
\begin{array}{r}
f_{1}(y, z)=a_{1} \int_{0}^{y} x g(x) d x+\int_{y}^{y+z}\left[a_{1} y+a_{2}(x-y)\right] g(x) d x+ \\
+\int_{y+z}^{\infty}\left(a_{1} y+a_{2} z\right) g(x) d x-b_{1} y
\end{array}
$$

The first part of the formula refers to when need is lower than $\mathrm{y}$, then the building depot can cover it from its own stock. In this case, his profit per unit is $a_{1}$. The second part refers to when $y+z$ $\geq x \geq y$. In this case, the building depot covers $y$ amount from its own stock, and the remaining $x-y$ need is covered by purchase. The third part refers to when $x>y+z$, where the building depot can't cover all needs from its own stock, therefore, it satisfies $y$ from its own stock, and $z$ from purchase, namely the logging company's stock. The fourth part of the formula refers to the cost of deposit. Based on the same correlation, the anticipatory profit of the logging firm is as follows:

$$
f_{2}(y, z)=a_{3} \int_{y}^{y+z}(x-y) g(x) d x+\int_{y+z}^{\infty} a_{3} z g(x) d x-b_{2} z
$$

With this, I defined a two-person game of infinite kind. If we propose that $y$ 's permissive values are $y_{1}, y_{2}, \ldots \ldots y_{\mathrm{m} 1}$ and $z$ 's permissive values are $z, z_{2}, \ldots . . z_{\mathrm{m} 2}$, while we allow mixed strategies as well, then we have a bimatrix game (Molnár et al., 2010b):

$$
\begin{aligned}
& A=f_{1}\left(\left(y_{i}, z_{j}\right)\right)_{i, j=1}^{m 1, m 2} \\
& B=f_{2}\left(\left(y_{i}, z_{j}\right)\right)_{i, j=1}^{m 1, m 2}
\end{aligned}
$$

\section{Theory of cooperative games}

Primarily those market players and companies that can be defined well on the market can already apply Game Theory solutions well in the present practice. Game Theory mathematics, meaning the selection of suitable strategies supported by numbers, may happen in an exact manner. What currently doesn't generally apply to the 
selection of appropriate strategies is the practice of cooperative aim or strategic choice. The sustainability concepts make it unambiguous that a production/consummation goal system can be planned long-term if the use of resources is planned and in a synchronized manner. Sustainable development may not be realized without this cooperation. The cooperative attribute and the fact that market players form coalitions provides a new approach to the Game Theory approach, as well. This doesn't necessarily mean that the interests of players are the same regarding e.g. the distribution of costs, but during the cooperation, it is compulsory to abide by a collectively defined criteria system (Hardin, 1968).

During cooperative strategies, the players or market players have the natural aim of raising their profits by giving up on their autonomy partially or completely (Solymosi, 2009). By this method, a given group of players or all players cooperate with each other and perhaps form coalitions or even a single coalition. The natural requirement of the cooperation is that the participating players or market players must have a higher share of profits compared to those who do not take part in cooperation at all. In this case, the goal won't be the increase of personal profits, but the maximization of the cooperation's profits. This aim completes the criteria of sustainability, in other words, sustainable development, or economy's weak sustainability (Molnár-Kelecsényi, 2009).

Cooperative games will be defined with the following descriptions. $N=\{1, \ldots ., n\}$ is the set of players for which a given S subset is commonly known as a coalition: $S \subseteq N$. Let $S$ be the set of subsets or the set of coalitions. The $N$ base set is called complete coalition (Szidarovszky, 1978b).

\section{Conflict alleviation methods}

Conflict alleviation methods are one of the favored groups of cooperative Game Theory solutions. Of these, we can stress the importance of Nash's axiomatic solution, which used axiom sets to assure that the solution is always placed on the Pareto-line. And the Kálai - Smorodinsky solution can give the last possible point which is the achievable minimum or the solution of the conflict by defining the worst outcome point of the conflict (Molnar - Szidarovszky, 1994).

Conflict alleviation methods will be demonstrated with a twoperson case. In our example, let $S_{1}$ and $S_{2}$ be the players' strategy sets, and $\varphi_{1}$ and $\varphi_{2}$ the two payoff functions. The set of possible payoffs can therefore be as follows:

$$
H=\left\{\varphi_{1}(x, y), \varphi_{2}(x, y) \mid(x, y) \in S_{1} \times S_{2}\right\}
$$

In this case, as always, both players aim at maximizing their payoffs, but their respective payoffs are naturally dependent on the other player's strategy, and a general rule is that raising one player's payoff leads to a drop in the other's (Nowak - May, 1992). Therefore, our task is that we have to find a solution that is acceptable to both parties. Before each solution, we have to state that if there's no cooperation, both parties will get either a lower payoff, or a penalty.

General definitions:

$$
\boldsymbol{f}_{*}=\left(f_{1 *}, f_{2 *}\right)
$$

this will be our payoff vector, for which we assume that there is a $\left(f_{1}, f_{2}\right) \in H$, for which $f_{1}>f_{1^{*}}$ and $f_{2}>f_{2^{*}}$. The conflict is defined mathematically by the $\left(H, f_{*}\right)$ pair. This pair was defined in Figure 2. We will also assume that set $H$ is closed, convex and bounded, which therefore means that:

$$
\left(f_{1}, f_{2}\right) \in H \text { and } \bar{f}_{1} \leq f_{1}, \bar{f}_{2} \leq f_{2}
$$

for which $\left(\bar{f}_{1}, \bar{f}_{2}\right) \in H$ essential, and bounded in both coordinates, therefore

$$
\sup \left\{f_{i} \mid\left(f_{1}, f_{2}\right) \in H\right\}<\infty
$$

in case of $i=1,2$.

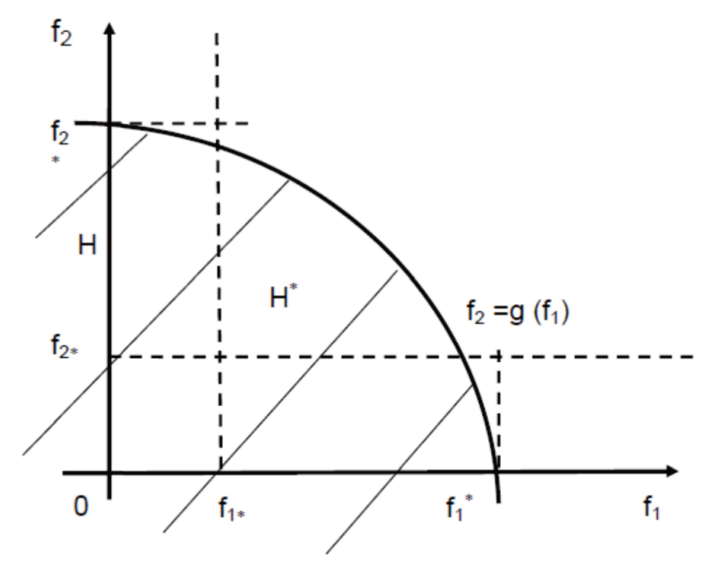

Figure 2: Graph of conflict

Source: based on Molnár-Szidarovszky, 2011c

Furthermore, we also assume that H's borderline is the graph of function $f_{2}=g\left(f_{\mathrm{x}}\right)$, which is strictly decreasing in point $f_{1}$ and concave. The graph of function $\mathrm{g}$ is usually called the Pareto line, therefore the optimum criteria for sustainability can only be satisfied here. Between the game and solution dependencies, we have to take note that no rational player will accept a partnership which means a worse payoff than a payoff without any partnerships.

Therefore, the possible payoff set can be narrowed as such:

$$
H^{*}=\left\{f_{1}, f_{2} \mid f_{1} \geq f_{1^{*}}, f_{2} \geq f_{2^{*}},\left(f_{1}, f_{2} \in H\right\}\right.
$$

\section{Model of oligopolistic games}

Oligopolistic game solutions are the most popular for the modeling of economic decision processes. They can be used for both cooperative and non-cooperative strategies; however, in my dissertation, I wish to present the cooperative model to define the sustainable maximization of the usefulness function, due to the importance of the sustainability attribute system.

There may be two relevant problems of economic science in the case of the usefulness function. The first problem was that the consumers aren't only defined by one usefulness function, but by an unlimited number of functions, and they are equivalent to each other. The second came up when the choice was made during insecurity. The solutions used on oligopolistic games can maximize the players' usefulness functions with the highest probability when the criteria are fixed and the strategies used are cooperative (Simonovits, 2003; Ichiishi, 1983).

In the wide scale of engineering (environmental protection) tasks, we can meet with exact problems that have a mathematical model which may be reduced to an oligopolistic game. Multiplayer Game Theory may be used to examine many variations of problems (Szilágyi, 2005). In the following example, I'll try to introduce the process of optimum search based on oligopolistic games by concentrating on a single product in the market process (this could be, e.g. green energy on the energy market), and by including market players and groups (manufacturers, transporters, regulators, implementers, etc.), who have an impact on the changes of the product's cost, and the creation of the point of equilibrium. 
In case of cooperative games, giving up on independence must result in the raise in profits for players (Simonovits, 2003).

General definitions for cooperative games:

$\varphi_{k}-$ payoff function

$S_{k}-$ strategic sets $\left(x_{1}{ }^{*}, \ldots x_{n}{ }^{*}\right)-$ strategic attributes

$n-$ a certain positive integer

$k$ - a certain set of $S_{k}$

Condition: for $=1,2,3 \ldots, n, x_{k}^{*} \in S_{k}$, and for every given $x_{k} \in S_{k}$

$$
\varphi_{k}\left(x_{1}^{*}, \ldots, x_{n}^{*}\right) \geq \varphi_{k}\left(x_{1}^{*}, \ldots, x_{k}^{*}, \ldots, x_{n}^{*}\right) .
$$

The inequality could be defined in words as such: for the $k$-th player $(1 \leq k \leq N)$, the equilibrium strategy is the optimal strategy, assuming the other players choose the correct equilibrium strategy. The cooperative game results in a coalition where the coalition itself can always generate profits unlike those who are not members.

Maximum of cooperative game, profits of coalition:

Let's assume that a set $M$ of players $k$ makes the

$$
M=\left\{i_{1}, i_{2}, \ldots, i_{k}\right\}
$$

coalition. Furthermore, let us take the game defined by

strategy sets, and

$$
X=x_{j=1}^{k} S_{i j} \text { and } Y=x_{l \neq i_{j}} S_{l}
$$

$$
\tilde{\varphi}_{1}(x)=\sum_{j=1}^{k} \varphi_{i_{j}}(x), \quad \tilde{\varphi}_{2}(x)=-\tilde{\varphi}_{1}(x)
$$

payoff functions. It is obvious that function $\tilde{\varphi}_{1}$ 's , ,max-min” value, meaning

$$
v(M)=\max _{x_{i_{j}}} \min _{x_{l_{(l \neq i j)}}} \tilde{\varphi}_{1}(x) \text { and } v(\varnothing)=0
$$

quantity - in which it exists - is only dependent on set $M$. The coalition assumes that players not in the coalition aim at minimizing the coalition's profits.

\section{Example for oligopolistic problem handling.}

To keep it simple, let's assume that $M=1, i_{1}=\ldots=i_{n}=1$, meaning we only examine a single product, and every group consists of a single unit. Referring to the known max-min function, $f$ can be differentiated into the $[0, \xi]$ interval. Let $\mathrm{I}=\left\{i_{1}, \ldots . i_{r}\right\} \subset\{1, \ldots, N\}$ be a coalition (Molnár - Szidarovszky, 1994).

In this case, $v(I)$ can be as follows:

$v(I)=\max _{x_{i}} \min _{x_{j}} \sum_{i \notin I} \varphi_{i}(\boldsymbol{x})$, where $\max \rightarrow i \in I$ and $\min \rightarrow j \notin I$.

To calculate value $v(I)$, first we need to calculate the

$$
\min _{\mathrm{x}_{\mathrm{j}}} \varphi_{i}(\boldsymbol{x})=\psi_{I}\left(x_{i_{1}} \ldots \ldots, x_{i_{r}}\right) \text { where } j \notin I
$$

quantity.

We differentiate two possible cases during problem solution:

$1)$ is if $\sum_{j \neq I} L_{j} \geq \xi$, then obviously

$$
\psi_{1}\left(x_{i 1} \ldots, x_{i r}\right)=-\sum_{i \in I} K_{i}\left(x_{i}\right)
$$

$2)$ is if $\sum_{j \notin I} L_{j}<\xi$, then obviously

$\psi_{1}\left(x_{i 1} \ldots, x_{i r}\right)=\left(\sum_{i \in I} x_{i}\right) f\left(\sum_{j \notin I} L_{j}+\sum_{i \in I} x_{i}\right)-\sum_{i \in I} K_{i}\left(x_{i}\right)$

In our first case, function $\psi_{1}$ 's maximum point is based on functions' $K_{\mathrm{i}}$ 's increase, meaning $x_{\mathrm{i} 1}=, \ldots=x_{\mathrm{ir}}=0$, therefore,

$$
v(I)=-\sum_{i \in I} K_{i}(0)
$$

Let's introduce the $L_{I}=\sum_{i \in I} L_{i}$ and $L_{I}^{\tilde{x}_{I}}=\sum_{j \notin I} L_{j}$ definitions for our second case.

Then, according to the formula above:

$\psi_{1}\left(x_{i 1} \ldots, x_{i r}\right)=s_{I} f\left(\tilde{L}_{I}+s_{I}\right)-\sum_{i \in I} K_{i}\left(x_{i}\right)$ where $s_{1}=\sum_{i \in I} x_{i}$

We can solve the above written equality with a programming task. We can use dynamic programming for the numeric solution (Molnár - Szidarovszky, 1994; Simonovits, 2003).

\section{Method of equal compromise}

The search for the solutions to environmental problems can be solved in different ways, as I've already mentioned at the beginning of the chapter; therefore, the optimum point, conclusion point or solution can manifest on the Pareto line in multiple coordinates. The method we use is dependent on the attitude of the one who does the optimization, his beliefs, intuition, and the nature of the processed problem (Axelrod, 1984).

Out of all the employable conflict alleviation methods, I chose the method of equal compromise to demonstrate the Game Theory solution, which (in case of two players) assumes that both players reduce their requirements at the exact same pace, to the point where they arrive at a possible solution. One of the method's characteristics is that there is usually a single solution point, and giving it outlines the optimal criteria system for the players (Forgó et al., 2005). This means that they accept the first solution (which is probably the best possible for both of them) as the solution to the conflict, or conclusion point. If both players want the maximum payoff, the $\left(f_{1}^{*}, f_{2}^{*}\right)$ point is needed, which is not possible.

In case of continuously and collectively decreased requirements, the problem's definition (if the solution is $\left(f_{1}, f_{2}\right)$, the two players always give $f_{1}^{*}-f_{1}$ and $f_{2}^{*}-f_{2}$ discounts, therefore, in case of equal discounts:

$$
f_{1}^{*}-f_{1}=f_{2}^{*}-g\left(f_{1}\right)
$$

Transforming the equation to $f_{1}$ :

$$
f_{1}-g\left(f_{1}\right)+\left(f_{2}^{*}-f_{1}^{*}\right)=0
$$

where we see the left side strictly increasing, for $f_{1}=f_{1^{*}}, f_{1^{*}}-$ $-f_{2}^{*}+\left(f_{2}^{*}-f_{1}^{*}\right)<0$ and for $f_{1}=f_{1}^{*}, f_{1}^{*}-f_{2^{*}}+\left(f_{2}^{*}-f_{1}^{*}\right)>0$, therefore, there is exactly one solution for the problem (Molnár Szidarovszky, 1995).

\section{Conclusions and summary}

My hypothesis is that the previously introduced non-cooperative and cooperative Game Theory solutions are applicable to mathematically defining sustainability criteria, since they allow the determination of points of equilibrium for economic, production, and strategic creation and planning processes, which create a clear basis for both long-term sustainable resource usage, and avoidance of economy development processes which have a detrimental effect. During the control and implementation of the Game Theory method, we refer to the „Layer by layer method,” meaning row after row solution of Rubik's Cube, which has the characteristic of being applicable to modeling the process of project development and the attributes that have an impact on each other during the development, through the logical sequence.

According to the hypothesis on the solution algorithms of the Rubik's Cube, the parts rotated next to each other, meaning the project attributes which have an impact on each other, have a relation system which can be defined in mathematical terms, therefore, their point of balance (e.g. Nash's) can also be determined by Game Theory models (games of finite kind, zero sum games, oligopolistic games, etc.) 
My analyses on Game Theory strategy models show that in today's practice, we can find a multitude of economic strategy models that don't really work as intended. The reason for this is basically the over-complication of the models and the inclusion of the multitude of factors and criteria. In order to save the process of modeling and the actual mechanisms of the models from falling into the category of „too complicated, no thanks,” we require a simplified and yet correctly working model that is easy to interpret, can be properly loaded with different data, and easy to correct. During the analysis of the Game Theory models and the strategic optimum search systems, I came to the conclusion that it is more beneficial to use smaller, individual and unique Game Theory solutions which have different reactions in a business environment to describe the process of equilibrium search instead of using complex multi-factor model-structures to describe the entire process in the form of functions. In case of development processes for renewable energy production, in other words, advancement from fossilized to renewable energy sources, by dividing the development program to three levels, then using noncooperative Game Theory method for the first, constant or zero sum game for the second, and finally, to define output criteria, cooperative Nash-equilibrium search with multi-player oligopolistic game for the third, offers a more beneficial result.

The unorthodox Game Theory method I described suggests during the phase of actual use - that we use function characteristics which are flexible time-wise for the various levels (input and output), therefore, it may prove applicable to model more complicated processes, if we form an optimum search process by a consecutive use of many simple Game Theory models. These methods/games can also be changed, and flexibly adapted to different economic criteria systems, according to the changes in business environment.

\section{References}

[1] Axelrod, R. (1984) The Evolution of Cooperation. New York, Basic Books, 1984. pp. 3-8. http://wwwee.stanford.edu/ hellman/Breakthrough/book/pdfs/axelrod.pdf [2] Forgó, F. - Pintér, M. - Simonovics, A. - Solymosi, T. (2005) Játékelmélet. Elektronikus jegyzet, BME Budapest, OTKA T046196 2005 pp. 17

[3] Forgó, F. - Szép, J. - Szidarovszky, F. (1999) Introduction to the Theory of Games. Kluwer Academic Publisher, Dordrecht, 1999 pp. 22

[4] Hardin, G.: The tragedy of the Commons. Science 162, 1968 pp. 1241-1248.

[5] Harsányi, J. (1995) A racionális viselkedés alapjai. Magyar Szociológiai Társaság, Tanulmányok, 1995/ 4. szám, Budapest 1995 pp. 1-5.

[6] Harsányi, J. (1995) A racionális viselkedés alapjai. Magyar Szociológiai Társaság, Tanulmányok, 1995/ 4. szám, Budapest 1995 pp. 24-25.

[7] Hobson, E. (2012) Can Game Theory be Applied to Family Law Negotiations?: Round Two. Family Law Dispute Resolution, 2012 pp. 3-7

http://www.riverdalemediation.com/

wp-content/uploads/2009/07/Hobson-Can-game-theory-beapplied-to-family-law-negotiations-round-two.pdf

[8] Ichiishi, T. (1983) Game theory for economic analysis; Academic press, New York 1983 pp. 10

[9] Mező, I. (2011a) Játékelmélet. Unideb.hu, Debreceni Egyetem, Debrecen, 2011, pp. 6-8
[10] Mező, I. (2011b) Játékelmélet. Unideb.hu, Debreceni Egyetem, Debrecen, 2011, pp. 9

[11] Mészáros, J. (2005) Játékelmélet, Gondolat Könyvkiadó Kft., Budapest, 2005 pp.12-15

[12] Molnár, S - Szidarovszky, F. - Molnár, M. (2010a) Játékelmélet és döntési módszerek. Szent István Egyetem. Egyetemi jegyzet, Gödöllő, 2010 pp. 25-27

[13] Molnár, S. - Szidarovszky, F. - Molnár, M. (2010b) Játékelmélet és döntési módszerek. Szent István Egyetem. Egyetemi jegyzet, Gödöllö, 2010 pp. 30-33

[14] Molnár, S. (1994) On the optimization of INPUT-OUTPUT systems cost functions, Pure Mathematics and Applications, Vol. 5. No. 4, 1994, pp. 404

[15] Molnár, S. - Szidarovszky, F. (1994) A diszkrét idejü oligopólium játékok stabilitásáról, SZIGMA, Vol. 25. No. 3, Budapest, 1994 pp. 103-105

[16] Molnár, S. - Szidarovszky, F. (1995) A folytonos idejü termelői-fogyasztói modellek stabilitásáról, SZIGMA, Vol. 26. No. 3-4., Budapest, 1995 pp. 95

[17] Molnár, S. - Szidarovszky, F. (2011a) Játékelmélet. Többcélú optimalizáció, konfliktuskezelés, differenciáljátékok. ComputerBooks, Budapest, 2011 pp. 16-17

[18] Molnár, S. - Szidarovszky, F. (2011b) Játékelmélet. Többcélú optimalizáció, konfliktuskezelés, differenciáljátékok. ComputerBooks, Budapest, 2011 pp. 18-19

[19] Molnár, S. - Szidarovszky, F. (2011c) Játékelmélet. Többcélú optimalizáció, konfliktuskezelés, differenciáljátékok. ComputerBooks, Budapest, 2011 pp. 46-47

[20] Molnár, S. - Kelecsényi, S. (2009) Hungarian National Climate Change Strategy Mitigation, adaptation and a low carbon economy. CIRCLE-APM, 2009. pp. 22.

[21] Nagy, G. (2008a,b,c) Megoldáskereső Módszerek. Informatikai szakdolgozat. Debreceni Egyetem Informatikai Kar, Debrecen, 2008, pp. $12-16$, pp. $22-25$, pp. $40-45$

[22] Neumann, J. - Morgenstern, O. (2007) Theory of Games and Economic behavior. Sixtieth-Anniversary Edition. Princeton University Press, New Jersey, 2007 pp. 13.

[23] Nowak, M. - May, R. (1992) Evolutionary games and spatial chaos. Nature 359, 1992 pp. 826-827.

[24] Simonovits, A. (2003) Neumann János és a játékelmélet Természet Világa, 2003. III. különszám, Neumann-emlékszám Különszámaink /Neumann emlékszám, pp. 1.

(http://www.termeszetvilaga.hu)

[25] Solymosi, T. (2009) Kooperatív játékok. Magyar Tudomány. A Magyar Tudományos Akadémia Lapja. 2009/05 pp. 547 http://www.matud.iif.hu/2009/09maj/05.htm

[26] Szidarovszky, F. (1978a) Nash-féle kooperatív megoldási koncepció általánosításáról. Szigma, Budapest, 1978 pp. 70

[27] Szidarovszky, F. (1978b) Játékelmélet. ELTE TTK jegyzet, Budapest, 1978 pp. 7-9.

[28] Szidarovszky, F. - Molnár, S. (1986) Játékelmélet müszaki alkalmazásokkal. Müszaki Könyvkiadó, Budapest 1986 pp. 220225

[29] Szidarovszky, F. - Molnár, S. - Molnár, M. - Fogarassy, Cs. (2013) Modeling Conflicting Interests in Water Distribution Problem with Game Theory. University of Arizona. (2013) pp. 162-165

[30] Szilágyi, M. (2005): Találkozás a játékelmélettel, Beszélő folyóirat, 2005. június- július, Évfolyam 10, Szám 6 pp. 1

[31] Vincze, J. (2009) A játékelmélet és gazdasági intézmények. Magyar Tudomány. A Magyar Tudományos Akadémia Lapja. 2009/05 pp. 568 http://www.matud.iif.hu/2009/09maj/07.htm 